\title{
12. Zuhura the African Lioness: Performance Poetry, Digital Media and the Transnational Tangle in World Literature
}

Paula Uimonen

Social Anthropology, Stockholm University

African lions

African lionesses

African warriors

African children

African brothers

African sisters

It is time to rise

Let them see you rise

Let them see you rise

The poet Zuhura Seng'enge concludes her performance with these lines from her poem Warrior Unleashed. She holds the microphone steadily in her hand as she articulates the words with theatrical emphasis, slowly moving closer to the audience, her steps in rhythm with the instrumental music that punctuates her words. As she repeats the last line after a dramatic pause, "Let them see you rise", carefully enunciating each word, Zuhura nods her head towards the audience, a gesture expressing complicity as well as collective agency. As soon as she ends, with a polite "Thank you very much", the audience breaks out in loud cheers and

How to cite this book chapter:

Uimonen, Paula. "Zuhura the African Lioness: Performance Poetry, Digital Media and the Transnational Tangle in World Literature". In World Literatures: Exploring the Cosmopolitan-Vernacular Exchange, edited by Stefan Helgesson, Annika Mörte Alling, Yvonne Lindqvist, and Helena Wulff, I29-I39. Stockholm: Stockholm University Press, 20I8. DOI: https:// doi.org/IO.I6993/bat.l. License: CC-BY. 
applause. The launch of Zuhura's first poetry collection, Warrior Unleashed, is clearly a success. Staged at the Soma Book Café in Dar es Salaam on I 5 July 2016, the event has attracted a small audience of friends, many of them artists: poets, writers, musicians and dancers. The program stretches over three hours, alternating between Zuhura's poetry performances as well as music, dance, rapping and poetry readings by other young artists, some of them performing in public for the first time. The audience is predominantly Tanzanian, with a few mzungu (white person), including myself, a Swedish anthropologist doing fieldwork on women writers in Tanzania (see www.womenwriters.one).

In this chapter, I discuss the multilayered location and multidirectional orientation of Zuhura's performance poetry in terms of transnational tangle in world literature. On social media, Zuhura calls herself Zubura the African Lioness, a multilayered cultural identity that captures a sense of belonging to the world at large as well as a specific place in it. Similarly, Zuhura's cultural perspective is multidirectional: she looks at the world from an African perspective, but she also engages with Africa from a global perspective. Rather than viewing the cosmopolitan/vernacular or global/local in world literature in terms of binary opposites, it is worth looking more closely at the interactions and entanglements that take place in between, in what I call the transnational tangle, thus building on anthropological theories on cosmopolitanism, globalisation and digital media ${ }^{\mathrm{I}}$ as well as world-making in literature. ${ }^{2}$ As an analytical tool, the transnational tangle seeks to capture the multifaceted complexity of location and orientation in an interconnected world where the intricate entanglements of

I Ulf Hannerz, "The global ecumene as a network of networks", in Conceptualizing Society, ed. Adam Kuper (London: Routledge, I992), 34-55; Ulf Hannerz, "Cosmopolitanism", in Companion to the Anthropology of Politics, ed. Joan Vincent and Daniel Nugent (Oxford: Blackwell, 2007), 69-85; Paula Uimonen, Digital Drama: Teaching and Learning Art and Media in Tanzania (New York: Routledge, 2012).

2 Peng Cheah, "What Is a World? On World Literature as World-Making Activity", Daedalus I37, no. 3 (2008): 26-38; Peng Cheah, "World against Globe: Toward a Normative Conception of World Literature", New Literary History 45, no. 3 (2014): 303-29 
the local and the global defy the structural binarism of "either/or," instead pointing to "both/and".

The aesthetics of Zuhura's performance poetry is illustrative of a transnational tangle in literary production that mixes genres of various spatiotemporal origin, creatively blending literature, orature, music and theatre. In this genre, the sounds of poetic articulation are just as important as the words themselves, while the artist's voice is augmented through music, thus merging literature, orature and music. Similarly, performance poetry collapses distinctions between literature and theatre. Although it is true that all literary readings are performative acts, ${ }^{3}$ in the case of performance poetry, it is intrinsic to the genre. Interestingly, while anthropologist Hastrup uses poetry (language) as a point of comparison with theatre (acting), in performance poetry these art forms merge, thus combining the magic of performance in theatre ${ }^{4}$ with imaginary literary world-making. ${ }^{5}$ Indeed, it is in interaction with the audience that performance poetry functions best, an embodied art form that relies on language as well as acting, on a stage that serves as a site of passage where possible experiences are created and secret worlds are revealed. ${ }^{6}$ By merging various genres, Zuhura's performance poetry constitutes a transnational tangle of both local/vernacular and global/cosmopolitan aesthetics that is far more multifaceted than the sum of its various parts.

Zuhura started exploring performance poetry in 20I4, while in her second year at the University of Dar es Salaam. ${ }^{7}$ She saw a poster for a La Poetista event and although she felt scared she went for a first rehearsal. It was the first time she memorised a poem. The organisers were very helpful, coaching her along and encouraging her to "be the poem". Zuhura practiced at home,

3 Helena Wulff, "Literary Readings as Performance. On the Career of Contemporary Writers in the New Ireland", Anthropological Journal of European Cultures, I7 (2008): 98-II3.

4 Kirsten Hastrup, "Theatre as a Site of Passage. Some Reflections on the Magic of Acting”, in Ritual, Performance, Media, ed. Felicia HughesFreeland (New York: Routledge, I998), 42.

5 Cheah, "What is a World".

"Hastrup, "Theatre as a Site of Passage".

7 Interview with Zuhura Seng'enge in Dar es Salaam on 2I July 20 I6. 
in front of the mirror and her sister. When she went back for a second rehearsal, she was told "you're a natural". She then performed at a large event at the Goethe Institute to a mostly non-Tanzanian, expatriate audience. Afterwards she was invited to perform at Open Mic events in Dar, to mostly Tanzanian audiences. Her confidence grew and nowadays she only does readings at poetry readings; otherwise she performs her poetry with live or recorded music.

While performance poetry comes across as a very contemporary art form, Zuhura's passion for poetry is rooted in a vernacular literary tradition, which she aims to revitalise. When asked what she hopes to achieve through her writing, Zuhura explained that she wants to bring back poetry in Tanzania as a respected literary genre. ${ }^{8}$ She recalled how poetry used to be valued more than any other art form. Nowadays film and music are more popular and literature is seen as ancient, especially poetry, Zuhura lamented.

Zuhura's ambition to "bring back respect for poetry" is instructive of her cultural rootedness in a vernacular literary tradition, while her efforts to do so convey a cosmopolitan sensibility. As a Tanzanian artist, Zuhura values the national cultural heritage, like the national poet Shabaan Roberts, whose role in the Tanzanian independence movement is still celebrated. But while Shabaan Roberts is praised for writing in Kiswahili, ${ }^{9}$ Zuhura writes mainly in English. In the Warrior Unleashed collection, only three poems are in Kiswahili: Uzuri wako (your beauty), Ndoto kubwa (big dream) and Home Sweet Home, which has a title in English. Most of the poems are in English, and one is bilingual. This is not to suggest that the content is delocalised. The bilingual poem What Binds Us is a tribute to the nation, emphasising the national unity of Tanzanians as "one people". Zuhura herself has grown up with three languages, her tribal language Kisambaa, Kiswahili and English. Zuhura prefers to write in English, which is also the language that she mostly reads in.

${ }^{8}$ Interview with Zhura Seng'enge in Dar es Salaam on 4 July 2016.

9 Ngugi wa Thiong'o, Decolonising the Mind: The Politics of Language in African Literature (London: James Currey, I986). 
English is a common language in the small circle of writers that Zuhura interacts with, an important social world and professional network, which is bilingual in its interaction. While Kiswahili is highly valued by these writers, it is also considered limiting when it comes to reaching a broader audience, since few works get translated into other languages. English thus offers a transnational lingua franca that mediates intercultural interaction, indicative of a cosmopolitan openness to and interest in cultural diversity. ${ }^{\text {Io }}$

In her efforts to revive poetry in Tanzania, Zuhura draws upon digitally mediated transnational resources. She reinvents traditional literature through digital media (CD, computer-recorded music, digital light and sound equipment) and a global lingua franca (English), thus repositioning and rethinking national cultural production in the wider context of transnational interactions, mediated through social and mobile media. Zuhura's first poetry collection, Warrior Unleashed, was released on CD, not in print. Over time, she has produced videos, and her second poetry collection was released online. ${ }^{\text {II }}$

Zuhura's performance poetry sheds light on the complex entanglements in world literature, a transnational tangle of cultural blending. Rather than seeing the cosmopolitan/global/transnational and the vernacular/local/national as opposite ends of a spectrum, thus emphasising binary categories, it is worth exploring the space in between. "Tangle" visualises the complexities of this in-betweenness. A tangle is closely related to "network", which has a long history in the anthropology of globalisation, dating back to Hannerz's conceptualisation of the global ecumene as a network of networks. ${ }^{\mathrm{I2}}$ Thinking of the social organisation of culture in world society in terms of a network of networks is particularly useful in relation to the Internet, which is generally defined as a network of networks. ${ }^{\mathrm{I} 3}$ While networks point to transnational connections of

ı Hannerz, "Cosmopolitanism”.

ir Paula Uimonen, "Digital Infrastructure in World Literature”, Anthropology and Humanism, forthcoming.

ז2 Hannerz, "The Global Ecumene".

s3 Uimonen, Digital Drama. 
exchange and interaction, transnational tangle captures and structures the multifaceted complexity of these connections.

Zuhura's performance poetry exemplifies the multilayered location and multidirectional orientation of a transnational tangle. She refers to herself as an African Lioness, rather than a more local form of identity, yet her African identity encapsulates many layers of belonging. Zuhura's cultural identity ranges from the very local to the global: ethnic (Sambaa), national (Tanzanian), regional (African) and global (cosmopolitan). In Warrior Unleashed, these multiple layers are expressed in various poems, switching between different languages and cultural contexts. In a poem of gratitude to her family, Home Sweet Home, Zuhura's eulogy expands from her own family to all families that support their children, just like her opening poem Cheers to the Women pays tribute to women in a variety of roles, in different settings. Zuhura's multilayered cultural perspective becomes even more poignant in poems that are explicitly focused on Africanness, shifting between the local and the global, the vernacular and the cosmopolitan. Beautiful Land praises the "great things in Africa" the "beautiful things", to counter how "when you talk about Africa, the first thing that comes to a person's mind is the suffering, the pain, the bad things, the blah blah, the ugly things", as Zuhura explained to the audience before performing the poem, thus addressing negative stereotypes so common in external portrayals of Africa.

When introducing Me and My Brown Skin, Zuhura remarked "So, if you are African, if you are not African, if you have a brown skin, if you don't have a brown skin, as long as you love your skin, this is for you". She proceeded with the opening line of the poem: "I asked God for a blessing and he blessed me with a brown skin", articulated in a smooth seductive voice, accompanied by jazzy tunes. The poem was inspired by some friends doing a movement on skin bleaching and the song Brown Skin by the AfricanAmerican artist India Ari that Zuhura had seen on YouTube. In tackling the politics of race crafting in an African context, ${ }^{\mathrm{I}}$ the

\footnotetext{
${ }^{14}$ Jemima Pierre, The Predicament of Blackness: Postcolonial Ghana and the Politics of Race (Chicago: University of Chicago Press, 2013).
} 
poem addresses Africa's place in the world, ${ }^{15}$ in racialised global hierarchies. But through the magic of performance poetry, another world is made possible, as Zuhura evokes an imaginary world where people love their skin, no matter the colour.

While this poem could be interpreted from the vantage point of her location (Tanzania/Africa), it is clear that Zuhura's orientation is transcultural, looking at the world from an African perspective and looking at Africa from a global perspective. Using her own brown skin to accentuate the poem, stroking her arm for emphasis, Zuhura's take on race and gender spans from personal embodiment to a worldwide imaginary. Not only does her poetry insist on the miraculous beauty of brown skin as opposed to a global political-aesthetic ideal of whiteness, but by insisting on worldwide inclusion, addressing Africans and non-Africans regardless of skin colour, she propagates harmonious co-existence and mutual respect, the kind of openness to cultural diversity that is the hallmark of cosmopolitanism.

It is through literature and digital media that Zuhura is able to express her multilayered cultural self and it is these forms of cultural mediation that also inspire and influence her multidirectional cultural expression. To date, Zuhura has never travelled outside of Africa and the first and only time she was on a plane was in 2015 when she attended a writers' workshop in Kampala, Uganda. Yet she has been exposed to cultural influences from other parts of the world since she was a child, especially through literature. Most of the literature she has read has been in English, by British or North American writers. In school she also read African literature, canonical works by writers like Chinua Achebe and Ngũgĩ wa Thiong'o, but she cannot remember reading anything by African women writers, possibly a poem, but not as compulsory reading. Nowadays she reads contemporary African writers like Chimamanda Ngozi Adichie as well as fellow poets and writers.

is James Ferguson, Global Shadows: Africa in the Neoliberal World Order (Durham: Duke University Press, 2006). 
Zuhura is an avid Internet user. Since she started with Facebook in 2012, she has acquired over I, 300 friends in her primary account and over 500 likes on another page. She also has a blog, a YouTube channel and a Twitter account. On the blog Zuhura Seng'enge's Poetry and Short Stories she posts some of her poems and stories, along with information about events. ${ }^{16}$ On her YouTube channel, she posts short videos from her live performances. ${ }^{17}$ On Twitter, Zuhura has over I 50 followers and uses the account to post short messages about her work and local literary events. ${ }^{18}$ In 20I6, Zuhura also started a WhatsApp group called Writers \& Editors of 2 IstC. Contrary to its generic name, the group consists of writers in Tanzania, mostly in Dar es Salaam, who share information about events, workshops and literary competitions as well as jokes about writing, in English and Kiswahili. ${ }^{19}$

For Zuhura, social media offers a chance to share and exchange with writers in Africa and outside Africa, a resource for learning and inspiration from "so many people", in her own words a "really big library". This sense of being connected with the world has less to do with the number of actual connections than the feeling of being interrelated with people around the world, thus illustrating how digital media can inspire a sense of membership in world society even in the peripheries of the global network society. ${ }^{20}$

Digital media can augment the world-making aesthetics of world literature. As argued by Cheah, ${ }^{21}$ world literature can be seen as a world-making activity, especially in relation to the cultural process of imagining the world as one. This comes close to an anthropological appreciation of world society in terms of the world as we know it, the global ecumene. ${ }^{22}$ Through literary

\footnotetext{
${ }^{16}$ http://zuhurasaad22.blogspot.com/, accessed on 28 April 2018.

${ }_{17}$ ZuhuratheAfricanLioness:https://www.youtube.com/channel/UCOi $5 \mathrm{IN}_{74}$ CDXnS 5 aFVYOB8fQ, accessed on 28 April 2018.

I8 Zuhura Seng'enge: @Zu_thelioness, accessed on 28 April 2018.

19 I have been a member of this group since July 2016.

${ }^{\circ}$ Ferguson, Global Shadows; Uimonen, Digital Drama.

${ }^{21}$ Cheah, "What Is a World?"

${ }^{22}$ Hannerz, "The Global Ecumene".
} 
production, different imaginary worlds are created, and through literary circulation, different people can engage with these imaginary worlds. As writers in different parts of the world connect with other writers as well as readers through digital media, literary world-making is expanded well beyond printed texts.

Digital media offers an interesting infrastructure of world literature that somehow challenges the global inequalities of literary production and circulation. ${ }^{23}$ Critical scholars have underlined the reproduction of global inequalities in world literary circuits, even defining world literature as the literature of the capitalist world system. ${ }^{24}$ Following Cheah, this emphasis on material conditions, social relations and political economic structures tends to ignore the aesthetic dimensions of literature, while conflating the categories world (imaginary) and globe (spatio-geographical). ${ }^{25}$ Digital media brings forth this conceptual shortcoming, while partially addressing it. On the one hand, digital media can inspire a cosmopolitan sense of the world as one, which transcends social and material boundaries. Through social media, Zuhura can express her poetry to a worldwide audience, thus using her literary talent to contribute to the making of imaginary worlds. In March 20I7, Zuhura even released some of her poems for free download on the site www.mkito.com, because the site makes it "easier to spread news about what you do to many people all over". ${ }^{26}$ On the other hand, digital infrastructure is intrinsically bound up with a global capitalist system that reproduces, at times even reinforces global racial hierarchies. ${ }^{27}$ When the African Lioness called on her brothers and sisters to rise, she used performance poetry to create an imaginary world that is more just and equal for all of humanity. But once the performance was concluded, Zuhura and her friends

${ }_{23}$ Uimonen, "Digital Infrastructure in World Literature".

${ }^{24}$ Warwick Research Collective (WReC), Combined and Uneven Development. Towards a New Theory of World-Literature (Liverpool: Liverpool University Press, 20I 5 ).

25 Cheah, "World against Globe".

${ }_{26}$ Facebook chat with Zuhura on I7 March 2017.

27 Paula Uimonen, “'Number not Reachable'. Mobile Infrastructure and Global Racial Hierarchy in Africa”, Journal des Anthropologues I42I43 (2OI 5): 29-47. 
in Dar faced a social reality in which most people cannot afford to buy a CD, or a book for that matter, and where the spectacular launch of the digitally mediated Warrior Unleashed was preceded by a few hours of power outage.

This study uses an anthropological approach that pays attention to women's literary production as well as the cultural context framing their work, thus offering a more nuanced understanding of the making of world literature. Such a holistic approach can be used to deconstruct some of the prevailing binaries in world literature studies and reconstruct a more culturally sensitive approach that allows for greater complexity.

In this text I have used transnational tangle to capture multifaceted cultural complexity in world literature, emphasising multilayered location and multidirectional orientation in contemporary literary production. Far from being bounded and static entities, location and orientation offer entry points into the cultural dynamics of transnational entanglements in world literature, the intricacies of which deserve further scrutiny. As glimpsed from Zuhura's performance poetry, young contemporary women writers in places like Tanzania draw on a variety of transnational resources, including digital media, to tell their stories in the world, of the world, and for the world in the making.

\section{Bibliography}

Cheah, Peng. "What Is a World? On World Literature as WorldMaking Activity”. Daedalus I37, no. 3 (2008): 26-38.

. "World against Globe: Toward a Normative Conception of

World Literature". New Literary History 45, no. 3 (20I4): 303-29.

Ferguson, James. Global Shadows: Africa in the Neoliberal World

Order. Durham: Duke University Press, 2006.

Hannerz, Ulf. “The Global Ecumene as a Network of Networks”. In Conceptualizing Society, edited by Adam Kuper, 34-55. London: Routledge, I992.

- "Cosmopolitanism". In Companion to the Anthropology of Politics, edited by Joan Vincent and Daniel Nugent, 69-85.

Oxford: Blackwell, 2007. 
Hastrup, Kirsten. "Theatre as a Site of Passage. Some Reflections on the Magic of Acting". In Ritual, Performance, Media, edited by Felicia Hughes-Freeland, 29-45. New York: Routledge, 1998.

Ngũgĩ Wa Thiong'o. Decolonising the Mind: The Politics of Language in African Literature. London: James Currey, 1986.

Pierre, Jemima. The Predicament of Blackness: Postcolonial Ghana and the Politics of Race. Chicago: The University of Chicago Press, 2013 .

Uimonen, Paula. Digital Drama. Teaching and Learning Art and Media in Tanzania. New York: Routledge, 20I2. http://innovativeethno graphies.net/digitaldrama.

- "'Number not Reachable.' Mobile Infrastructure and Global Racial Hierarchy in Africa”. Journal des Anthropologues I 42-I 43 (20I 5): 29-47.

—. "Digital Infrastructure in World Literature". Anthropology and Humanism, forthcoming.

Warwick Research Collective (WReC). Combined and Uneven Development. Towards a New Theory of World-Literature. Liverpool: Liverpool University Press, 2015.

Wulff, Helena. "Literary Readings as Performance: On the Career of Contemporary Writers in the New Ireland". Anthropological Journal of European Cultures I7 (2008): 98-II3. 